\title{
Physiological and Biochemical Characterization of Bacillus spp. from Polychaete, Perinereis aibuhitensis
}

\author{
Seyeon Shin', Khorloo Yundendorj', Sang-Suk Lee ${ }^{2}$, Kyoung-Ho Kang ${ }^{3}$ and Hyung-Yeel Kahng ${ }^{1}$ \\ ${ }^{1}$ Department of Environmental Education, Sunchon National University, Suncheon 540-742, Korea \\ ${ }^{2}$ Department of Animal Science \& Technology, Sunchon National University, Suncheon 540-742, Korea \\ ${ }^{3}$ Department of Aqualife Science, Chonnam National University, Yosu 550-749, Korea
}

Received December 26, 2012 /Revised February 20, 2013 /Accepted February 25, 2013

\begin{abstract}
This study compared the characteristics of five Bacillus strains capable of aerobic and anaerobic growth, CBW3, CBW4, CBW9, CBW14 and EBW10. They were isolated and selected from a polychaete, Perinereis aibuhitensis, which is known as a good degrader of organic compounds in marine wetland. Based on a 16S rRNA sequence, CBW3 and CBW14 were found to share more than $99.8 \%$ similarity with B. nanhaiensis, B. arsenicus and B. barbaricus. CBW4, CBW9 and EBW10 shared 92.7\%, $99.8 \%$, and $99.8 \%$ similarity with $B$. anthracis, $B$. algicoa and $B$. thuringiensis, respectively. The temperature, salinity, and $\mathrm{pH}$ ranges of the cell growth of the Bacillus strains were $4-45^{\circ} \mathrm{C}, 0-17 \%$, and $\mathrm{pH}$ 5-pH 9, respectively. All Bacillus strains were found to exhibit enzyme activities for the degradation of casein and starch. Notably, strain EBW10 exhibited the enzyme activities for all the tested macromolecules, DNA, casein, starch, cellulose, and four kinds of Tweens, which suggests the possibility that it had protease, amylase, cellulose, and lipase. All five Bacillus strains had alkaline phosphatase activities, and the strains CBW3, CBW4, and EBW10 also had acid phospatase. Strains CBW3 and EBW10 exhibited the enzyme activities both for esterase (C4) and esterase lipase (C8). The analysis of fatty acids revealed that in all strains, major fatty acids were anteiso $C_{15: 0}$ and iso $C_{15: 0}$
\end{abstract}

Key words : Bacillus spp., biodegradation, enzyme activity, marine wetland, Perinereis aibuhitensis

\section{서 론}

갯지렁이는 해양 무척추동물로 조간대 갯벌과 강 하구에 넓게 분포되어 있는 저서생물 중의 하나로, 스트레스를 받은 환경 조건에 대한 적응능력 때문에 연구자들은 이들 갯지렁이 들을 환경 파수꾼으로서 뿐만 아니라 모니터링 프로그램을 위해 잠재적으로 중요한 생태종으로 간주한다 $[6,12,36]$. 조간 대에 위치한 저서생물들은 흔히 가정이나 수서생태계에서 물 의 유기물을 제거하고 정화하는데 흔히 사용되며 $[7,9,35,50]$, 특히 Perinereis sp.를 비롯한 여러 종의 갯지렁이들이 새우 양 식장 환경에서 비통제 방식으로 사용되는 것으로 알려져 있다 [13]. 특히 부유성 세균의 영양학적 기능과 관련하여 갯지렁이 를 비롯한 여과 섭식자(suspension feeders)를 대상으로 폭넓 게 연구되어 왔으며[16, 34, 37], 갯지렁이 Sabella spallanzanii는 주위 환경으로부터 매우 효과적으로 박테리아를 축적하고 농

\footnotetext{
*Corresponding author

Tel : +82-61-750-3385, Fax : +82-61-750-3308

E-mail : kahng@sunchon.ac.kr

This is an Open-Access article distributed under the terms of the Creative Commons Attribution Non-Commercial License (http://creativecommons.org/licenses/by-nc/3.0) which permits unrestricted non-commercial use, distribution, and reproduction in any medium, provided the original work is properly cited.
}

축할 수 있는 능력이 있음을 보고한 바 있다[44].

Bacillus 종들은 해양환경에서 여러 해양 생물의 미생물상의 일부를 차지하는 것으로 알려져 있으며[21, 27], 그람 양성, 포 자 형성균으로 상업적으로 소화계와 면역계를 촉진할 수 있는 능력이 있어 프로바이오틱스(probiotics)로 사용되기도 한다 $[14,52]$. 특히, B. subtilis는 숙주의 자연적 소화 활동에 기여할 수 있는 단백질 분해효소와 다른 효소들을 생산할 수 있는 능력뿐만 아니라 많은 생물들의 먹이로 사용되는 것으로 알려 져 있다[49, 52]. B. subtilis는 항미생물제를 생산하거나 영양과 공간에 대한 경쟁을 통하여 잠재적인 병원성 미생물에 의한 숙주 생물 창자의 집락화를 방지하는 것으로 알려져 있다[48]. B. licheniformis는 항바이러스제를 생산하는 것으로 밝혀져 있 고[1], 해양 어류에서 흔하게 나타나는 B. pumilus는 소화 활동 에 관련된 주요 효소를 생산하는 것으로 알려져 있다[15, 45]. 흥미롭게도 B. subtilis를 B. licheniformis 또는 B. pumilus와 함 께 송어에 투여하였을 때 송어의 성장과 면역 저항성을 도울 수 있으며[2, 38], Bacillus의 몇몇 종은 새우 양식에서 항생제 대체제로 제안되고 있다[3].

본 연구는 연안 갯벌에서 유기물 분해능이 매우 우수한 것 으로 알려진 갯지렁이(Perinereis aibuhitensis)에 서식하고 있는 미생물 중 영양물질의 소화 및 생물면역과 밀접하게 연관된 것으로 알려져 있는 Bacillus균의 특성 분석에 초점을 맞추어 수행되었다. 


\section{재료 및 방법}

\section{균주 분리 및 배양 조건}

본 연구에서 균주 분리원으로 사용한 갯지렁이(Perinereis aibuhitensis)는 순천만 갯벌 양식장에서 채취하였다. 갯지렁이 내부에 존재하는 미생물을 분리하기 위해 살아있는 갯지렁이 를 Burk's Medium (BM) buffer [31] 50 ml가 포함된 conical tube에 넣은 후 vortex mixing후 세 번 세척한 다음, $70 \%$ ethanol에서 2-3초간 세척하였다. 멸균된 면도날로 세척한 갯지렁 이의 복부를 가르고 다시 여러 개의 매우 짧은 마디로 절단한 후, BM buffer $50 \mathrm{ml}$ 가 포함된 conical tube에 넣어 격렬하게 vortexing하여 갯지렁이 내생 미생물이 buffer 안으로 빠져나 오게 하였다. 이어서 갯지렁이를 제거한 후 $12,000 \mathrm{rpm}$ 으로 원심분리하여 pellet을 모아 $2 \mathrm{ml}$ 의 $\mathrm{BM}$ buffer를 첨가하여 잘 섞은 후 $100 \mu \mathrm{l}$ 씩 고체 Bacto marine agar 2216 (MA) (Difco) 배지에 접종하여 미생물을 배양하였다. MA 배지는 1:10과 1:2 로 희석한 배지 및 희석하지 않은 배지를 동시에 사용하여 배양법에 의하여 분석할 수 있는 미생물 다양성을 높이고자 하였다. 기타 환경조건별 균주의 생장 여부를 파악할 때는 분 리한 모든 균주가 Luria-Bertani (LB) [41] 배지에서 생장할 수 있었기 때문에 LB 또는 LB agar 배지를 기본배지로 사용하였 으며, 이들 균주 배양조건은 아래 환경 조건별 생장시험에 자 세히 나타내었다.

\section{Total genomic DNA 분리와 정제}

각 균주를 $50 \mathrm{ml}$ 의 $\mathrm{LB}$ 배지에 접종하고 $30^{\circ} \mathrm{C}$ 에서 $180 \mathrm{rpm}$ 으로 24 시간 동안 배양한 후 원심분리(6,300× $\left.\mathrm{g}, 10 \mathrm{~min}, 4^{\circ} \mathrm{C}\right)$ 하여 세포를 수확하였다. 회수된 배양세포를 $5 \mathrm{ml}$ TES buffer [0.1 M Tris-HCl (pH 7.0), 0.01 M EDTA, 1 M NaCl]로 재현탁 하고, lysozyme $(10 \mathrm{mg} / \mathrm{ml})$ 을 $200 \mathrm{\mu l}$ 첨가하여 $37^{\circ} \mathrm{C}$ 에서 15 분 간 반응시켰다. $10 \%$ sodium dodecyl sulfate (SDS)를 $100 \mu \mathrm{l}$ 첨가하고, 물리적인 DNA 절단을 방지하기 위하여 천천히 섞 어준 후 $50 \mu \mathrm{l}$ proteinase $\mathrm{K}(20 \mathrm{mg} / \mathrm{ml})$ 와 $5 \mu \mathrm{lNase}$ 를 첨가 하여 $37^{\circ} \mathrm{C}$ 에서 30 분간 반응시켰다. $5 \mathrm{ml}$ TES buffer를 더 첨가 하여 $10 \mathrm{ml}$ 의 phenol을 첨가하여 잘 섞어주었다. 원심분리를 통하여 얻어진 상징액을 취하여 새로운 tube로 옮긴 후 동량의 phenol/choroform/isoamyl alcohol로 2회, chlorofrom으로 1 회 처리하였다. 상징액을 취하여 새로운 tube로 옮긴 후 $1 / 10$ volume의 3M sodium acetate ( $\mathrm{pH}$ 5.4)와 2-3 fold volume의 $100 \%$ ethanol을 첨가하여 30 분간 실온에서 방치하였다. 원심 분리 후 상징액을 버리고 $70 \%$ ethanol을 처리하여 염류를 씻 어낸 후 다시 한 번 원심분리하였다. 상징액을 버리고 공기 중에서 ethanol을 제거한 후 침전물 $500 \mu \mathrm{l}$ 의 멸균수에 녹여 다음 실험에 사용하였다. $0.8 \%$ agarose gel에 전기영동을 실시 하여 DNA band를 확인한 후 UV-spectrophotometer (DU 800, Beckman Coulter, Fullerton, USA)를 이용하여 정량하였
다. Total DNA의 정제를 위해 crude DNA를 $10 \mathrm{ml}$ cesium chloride용액에서 녹인 후 ethidium bromide를 첨가하고 0.2 $\mu \mathrm{m}$ membrane filter를 이용하여 30분간 투석하여 DNA 용액 을 회수하여 농축한 후 특정 유전자의 증폭 또는 클로닝을 위한 시료를 사용하였다. 기타 언급하지 않은 여러 가지 분자 생물학적 방법은 이미 잘 알려진 방법[41]에 따라 수행하였다.

\section{$16 \mathrm{~S}$ rRNA 유전자 염기서열 및 계통관계 분석}

세균의 $16 \mathrm{~S} \mathrm{rDNA}$ 염기서열 분석은 분리 균주들을 액체 배지에서 $30^{\circ} \mathrm{C}$ 에서 2-3일 동안 배양한 후 이로부터 추출된 genomic DNA와 27F (5'-AGA GTT TGA TCC TGG CTC AG-3') 와 1522R (5'-AAG GAG GTG ATC CAR CCG CA-3')로 이루 어진 한 세트의 프라이머를 사용하여 이미 알려진 방법[30]에 따라 PCR을 수행하였다.

PCR 반응은 GeneAmp PCR System 9700 (Applied Biosystems, CT)를 사용하여 수행하였고, 반응 조건은 $95^{\circ} \mathrm{C}$ 에 서 5 분간 초기 열처리를 한 후, $95^{\circ} \mathrm{C}$ 에서 1 분, $55^{\circ} \mathrm{C}$ 에서 1 분, $72^{\circ} \mathrm{C}$ 에서 1 분씩 30 번 반복하였고, 이어 $72^{\circ} \mathrm{C}$ 에서 10 분간 처리 한 후 $4^{\circ} \mathrm{C}$ 에 반응액을 보관하였다. 증폭된 DNA는 $1.0 \%$ agarose gel에서 전기영동한 후 gel extraction kit (SolGent)에 의해 회수하였다. 회수된 DNA는 pGEM-T easy vector (Promega, Madison, Wisconsin)에 ligation한 후 E. coli JM109에 형질전 환하였다. 형질전환 된 클론의 플라스미드 DNA를 분리한 후 promoter primer나 SP6 promoter primer를 이용하여 ABI 377 자동염기서열 분석기(Applied Biosystem, Foster, USA)에 서 양방향으로 DNA sequencing을 수행하였다.

결정된 염기서열은 Ribosomal Database Project- $\Pi$ (http://rdp.cme.msu.edu)와 GenBank (http://ncbi.nlmnih.gov) 의 database를 이용하여 분석하였다. 염기서열이 결정된 미생 물의 계통관계는 EZtaxon server를 이용하여 type 균주들의 $16 \mathrm{~S}$ rRNA 염기서열과의 관계를 나타내었다[8]. Alignment는 CLUSTAL X 1.83 [47]에 의해 수행되었으며, 염기서열 간 gap 은 BioEdit 프로그램을 이용하여 편집하였다[20]. 계통도는 MEGA 5 program [29]의 neighbor-joining 방법[40]으로 그렸 고, 계통도의 지형은 bootstrap 분석[11]을 통해 평가되었다.

\section{갯지렁이 유래 Bacillus 균주의 생리학적 특성 시험}

절대 호기성 세균은 대사과정에서 필요한 에너지를 생성하 기 위해서 최종 전자수용체로서 산소를 이용하고, 절대 혐기 성 세균은 catalase가 없어서 산소에 노출되면 세포에 독성을 띠는 hydrogen peroxide $\left(\mathrm{H}_{2} \mathrm{O}_{2}\right)$ 가 축적되기 때문에 산소의 존재여부는 균 생장에 영향을 줄 수 있다. 본 연구에서는 호기 생장 여부와 함께 혐기성 조건에서 균들의 생장 여부를 알아 보고자 Oxoid사의 혐기성 배양기 안에 AnaeroGen ${ }^{\mathrm{TM}}$ 을 넣어 산소가 없는 조건을 만들어주고, $30^{\circ} \mathrm{C}$ 에서 48 시간 균을 배양 하여 조사하였다. 균의 운동성을 조사하기 위해 운동성 배지 
[10]을 제조한 후 순수 배양된 균을 멸균된 백금선을 사용하여 수직으로 중앙에 $2 \mathrm{~cm}$ 깊이까지 접종하고, $30^{\circ} \mathrm{C}$ 에서 24 시간 동안 배양한 후 관찰하였다.

그람 염색을 통한 세포 형태 및 크기 관찰은 Hucker의 방법 [22]에 따라 Gram 염색을 실시한 후 광학현미경을 통해 관찰 하였다. 세포벽이 두꺼운 waxy 물질로 덮여 있어서 염색이 쉽게 되지 않으며 일단 염색이 되면 acid alcohol로도 탈색이 되지 않는 성질을 항산성이라 하는데 항산성은 갯지렁이 Bacillus 균주들을 Ziehl-Neelsen의 방법[4]에 따라 염색한 후, 균체가 내는 색의 변화로 관찰하였다. Bacillus의 내생포자를 관찰하기 위하여 균주들을 Marine Broth (MB) 배지에 접종 후 $30^{\circ} \mathrm{C}$ shaking incubator에 24 시간 전배양한 균을 $60^{\circ} \mathrm{C}$ water bath와 $80^{\circ} \mathrm{C}$ water bath에서 10 분간 방치한 후 $\mathrm{MA}$ 배지에 도말하고 $30^{\circ} \mathrm{C}$ 에서 24 시간 배양한 균을 Moeller의 방법[32]에 따라 염색한 후 현미경으로 관찰하였다. Catalase 활성은 MA 배지에 48시간 동안 전배양한 균주에 $3 \% \mathrm{H}_{2} \mathrm{O}_{2}$ 를 한 방울 떨어 뜨려 기포 발생여부를 관찰하였고, oxidase 활성은 MA 배지 에 48시간 동안 전배양한 균주의 colony 한 개를 멸균된 이쑤 시개로 따서 filter paper 위로 옮기고 Kovács 시약[28] 한 방울 떨어뜨려 균주의 색이 변하는지 관찰하였다. Cytochrome oxidase system이 있는 균은 $\mathrm{H}_{2} \mathrm{O}_{2}$ 로부터 환원형의 cytochrome 의 산화를 통하여 산소를 생성하므로 30 초 이내로 균주의 색 이 보라색으로 바뀌면 양성판정을 하였다. 탄수화물의 발효는 다양한 유기산과 알코올을 형성하는데 본 연구에서는 $10 \%$ lactose가 포함된 Ammonium Salt Sugars (ASS) 배지에 균을 접종하여 균의 성장과 산의 생성 여부를 조사하였다. 균이 탄 수화물을 산화하는지 발효하는지 여부는 OxidationFermentation (OF) 배지[23]에 같은 균을 접종한 후 $30^{\circ} \mathrm{C}$ 에서 배양한 후 14 일간 매일 관찰하면서 판정하였다.

본 연구에서는 배지별 생장여부와 온도, $\mathrm{pH}$, 염도 등 세 가지 환경 조건을 달리하여 균주의 생장 여부를 조사하였다. 배지별 균 생장능은 이미 알려진 방법[41]에 따라 제조한 LB agar, Tryptic Soy Agar (TSA), Nutrient Agar (NA) 배지와 $\mathrm{MA}$ (Difco), R2A (Difco) 배지에서 $30^{\circ} \mathrm{C}$ 에 배양하여 조사하였 다. 온도별 균 생장능은 $\mathrm{MA}$ 고체 배지에 접종 후 $4-50^{\circ} \mathrm{C}$ 범위 에서 배양하여 조사하였다. 배양의 최적 $\mathrm{pH}$ 는 액체상의 $\mathrm{MB}$ 배지 제조 시 $10 \mathrm{~N} \mathrm{NaOH}$ 와 $6 \mathrm{~N} \mathrm{HCl}$ 을 이용하여 $\mathrm{pH} 3-\mathrm{pH}$ 11 까지 $\mathrm{pH}$ 1씩 차이를 두고 9 개 tube에 각각 접종한 후 $30^{\circ} \mathrm{C}$ 에 서 72 시간 배양하면서 생장 유무를 관찰하였다. 염도에 따른 균 생장의 영향을 알아보기 위해 MA 배지를 제조할 때 salts 성분을 제거해 염도 $0 \%$ 배지를 만들고 추가적으로 원하는 농 도만큼의 sea salts를 첨가하여 배지의 염도를 0-17\%까지 염도 $1 \%$ 씩 차이를 두고 만든 후 균을 접종, $30^{\circ} \mathrm{C}$ 에서 배양한 후 균들의 생장여부를 조사하였다. 균주의 생장 여부는 균주 접 종 후 각 균주의 적정 생장 온도에서 5 일간 배양하면서 생장여 부를 확인하였다.
갯지렁이 유래 Bacillus 균주의 탄소원 이용능 및 주요 효 소 활성 분석

탄소원 이용성 및 효소 활성 특성 조사는 API $50 \mathrm{CHB} / \mathrm{E}$, API 20 E, API ZYM kit를 사용하였다. API $50 \mathrm{CHB} / \mathrm{E}$ 는 Bacillus 동정에 사용되며 API $20 \mathrm{E}$ 는 $\mathrm{API} 50 \mathrm{CHB} / \mathrm{E}$ 의 결과를 보완하기 위해 사용하였다. 모든 시험은 incubation box를 준 비하고 증류수 $5 \mathrm{ml}$ 을 tray에 부어서 수분을 유지하도록 하였 다. API $50 \mathrm{CHB} / \mathrm{E}$ Test는 API $50 \mathrm{CHB} / \mathrm{E}$ medium의 뚜껑을 열고 배지에서 집락을 여러 개 취해서 $2 \mathrm{McFarland}$ 로 탁도를 맞추었다. 탁도를 맞춘 API $50 \mathrm{CHB} / \mathrm{E}$ medium을 스트립의 튜브에 분주하여 $30^{\circ} \mathrm{C}$ 에서 24-48시간 배양하여 결과를 판독하 였다. API $20 \mathrm{E}$ Test는 suspension medium $(5 \mathrm{ml})$ 의 앰플을 열고 배지에서 하나의 colony를 취한 후 골고루 부유하도록 하는데, 본 연구의 대상 균주들은 해양 생물로 API kit를 이용 하기 위하여 Sea Salts (SS) 3-4\% 용액에 부유시켰다. ᄂCIT 」, $\llcorner\mathrm{VP}\lrcorner,\llcorner\mathrm{GEL}\lrcorner$ 은 큐플까지 균액으로 가득 채우고 나머지 는 큐플을 제외하고 튜브만 채웠다. ADH, LDC, ODC, H2S, URE는 혐기적인 조건을 만들어주기 위해 광유(mineral oil)로 큐플을 채웠다. Incubation box를 호기적인 상태에서 $30^{\circ} \mathrm{C}$, $\mathrm{API} 50 \mathrm{CHB} / \mathrm{E}$ 와 같은 시간 배양하고 결과를 판독하였다. API ZYM Test는 suspension medium $(2 \mathrm{ml})$ 에 균을 풀어 탁 도를 5-6 McFarland로 맞추고 피펫을 이용하여 각 큐플에 65 lㅣ씩 분주하여 $37^{\circ} \mathrm{C}$ 에서 4 시간동안 배양하였다. 4 시간 뒤 스트 립을 꺼내어 ZYM A와 ZYM B 시약을 각각의 큐플에 한 방울 씩 떨어뜨리고, 5 분 후 결과를 판독하였다. 색의 변화정도에 따라 0 - 5까지의 값으로 표시하여 3이상인 반응을 양성으로 판정하였다.

\section{고분자 물질 분해 효소 활성 시험}

Bacillus 균들의 고분자 분해능을 알아보기 위해 DNA를 제 외하고는 기본배지를 $\mathrm{MA}$ 로 하고 carboxymethylcellulose (CM/cellulose, Sigma), soluble starch (Sigma-Aldrich), 그리 고 skim milk (Difco)를 각각 $1 \%$ 씩 첨가해 목적한 배지를 만든 후 각각의 배지에 균을 접종한 후 $30^{\circ} \mathrm{C}$ 에서 배양해 분해능을 확인하였다. 그리고 고분자 지질 분해 가능성을 알아보기 위 해 Tween 20 (Sigma), Tween 40 (Sigma), Tween 60 (Sigma), Tween 80 (Sigma)를 각각 1\%씩 첨가해 목적한 배지를 만든 후 각각의 배지에 균을 접종한 후 $30^{\circ} \mathrm{C}$ 에서 배양해 분해능을 확인하였다. DNA를 분해할 수 있는 효소인 DNase를 생산할 수 있는지 확인하고자 DNA가 함유된 배지에 균을 배양한 후 $1 \mathrm{~N} \mathrm{HCl}$ 을 부어 투명대가 형성되는지 확인하였다[25]. Cellulose 분해 여부 관찰시 congo-red (0.1\%)를 떨어뜨리고 30 분이 지난 뒤 $1 \mathrm{M} \mathrm{NaCl}$ 로 세척하였다. 균이 cellulose를 분해 할 경우 균체 주변에 희미한 노란색이 나타나는 것으로 cellulase 활성 여부를 확인하였다. Starch의 분해 여부는 균을 배양 한 후 Lugol's iodine을 부은 후 색변화를 관찰하였다. starch 
가 존재하는 부분은 진한 청색으로 변하고 starch 분해능이 있는 균체 주변은 투명대가 나타나는 것으로 amylase 효소활 성을 조사하였고, Casein 분해능은 균 배양 후 투명대 생성 여부를 확인하였다. Tween을 분해하는 균은 Tween을 포함하 는 배지에서 배양된 균체 주변이 뿌옇게 변하는 것으로 확인 하였다[43].

\section{세포막의 지방산 분석}

분리균주에 대한 세포지방산 분석은 $\mathrm{MIDI}$ 를 이용하여 수 행하였다. 이를 위하여 분리 균주를 $\mathrm{MA}$ 배지에서 $25^{\circ} \mathrm{C}$ 에서 72 시간 동안 배양하였다. 분석기기는 미생물 동정 시스템 (Microbial Identification System MIDI, Microbial ID. Inc., $\mathrm{DE}$ )을 사용하였으며, 분석된 데이터는 TSBA40 (Sherlock Version 4.0; Microbial Identification System MIDI, Microbial ID. Inc., DE)에서 검색하였다. 배양제 $40 \mathrm{mg}$ 을 루프로 캡튜브 에 취한 후 메탄올 : 증류수(methanol : D.W) 1:1 혼합용액에 $15 \%$ 수산화나트륨이 포함된 시약 $1 \mathrm{ml}$ 을 가하여 $100^{\circ} \mathrm{C}$ 에서 25 분간 반응시켜 세포내 지방산을 추출하였다. 추출된 지방산 의 메틸화를 위하여 $6 \mathrm{~N} \mathrm{HCl} 2 \mathrm{ml}$ 을 첨가하고 $80^{\circ} \mathrm{C}$ 에서 10 분 간 반응 시킨 후 재빨리 냉각시켰으며, 수용성의 상태인 지방 산을 유기상으로 전환시키기 위하여 hexane과 methyl - tert buthyl ether를 1:1 혼합한 용액 $1.25 \mathrm{ml}$ 을 첨가한 후 10 분 동안 회전시켜주어 상층액만을 취했다. 마지막으로 포화된 수산화

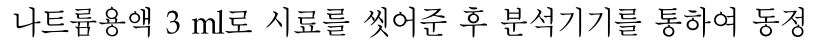

하였다.

\section{결과 및 고찰}

\section{갯지렁이 내생 Bacillus spp.의 계통관계}

갯지렁이 추출물을 접종한 $\mathrm{MA}$ 배지에서 생장하여 나타난 집락을 선별하여 순수배양한 후 $16 \mathrm{~S}$ rRNA 염기서열에 기초하 여 동정한 결과 12 균주가 Bacillus 속(genus)에 포함되는 것으 로 밝혀졌다(Data not shown). 그 중 호기성 및 혐기성 조건에 서 모두 생장 가능한 5 균주, CBW3, CBW4, CBW9, CBW14 그리고 EBW10을 선별한 후 $1295 \mathrm{bp}$ 의 $16 \mathrm{~S}$ rRNA 염기서열을 기초로 선별균주들 간의 계통관계를 분석하였다(Fig. 1). $\mathrm{CBW} 3$ 와 CBW14는 같은 종으로 B. nanhaiensis JSM082006 ${ }^{\mathrm{T}}$, B. arsenicus $\mathrm{Con} \mathrm{a} / \mathrm{3}^{\mathrm{T}}$, 그리고 B. barbaricus $\mathrm{V} 2-\mathrm{BIII}-\mathrm{A} 2^{\mathrm{T}}$ 와 $99 \%$ 이상의 높은 상동성을 나타내었고, $\mathrm{CBW} 4$ 는 이미 알려진 Bacillus 균주와 계통관계에서 비교적 거리가 먼 것으로 나타 났다. CBW9는 B. algicola $\mathrm{KMM} 3737^{\mathrm{T}}$ 와 $99.8 \%$, B. hwajinponensis SW-72 $3737^{\mathrm{T}}$ 와 B. hemicentroti JSM $076093^{\mathrm{T}}$ 와도 $97 \%$ 이상의 높은 상동성을 나타내었고, EBW10은 B. thruingiensis ATCC $10792^{\mathrm{T}}$ 와 $99.8 \%$ 의 높은 상동성을 보였다.

$\mathrm{CBW} 3$ 와 $\mathrm{CBW} 14$ 와 높은 상동성을 가지는 B. barbaricus V2-BIII-A2 $2^{\mathrm{T}}$ 는 실험벽 수채화로부터 분리된 세균으로 $B$. megaterium, B. flexus 그리고 B. cohnii와 $94 \%$ 이상의 상동성을 가 진 것으로 알려져 있다[46]. CBW9와 높은 상동성을 가지는

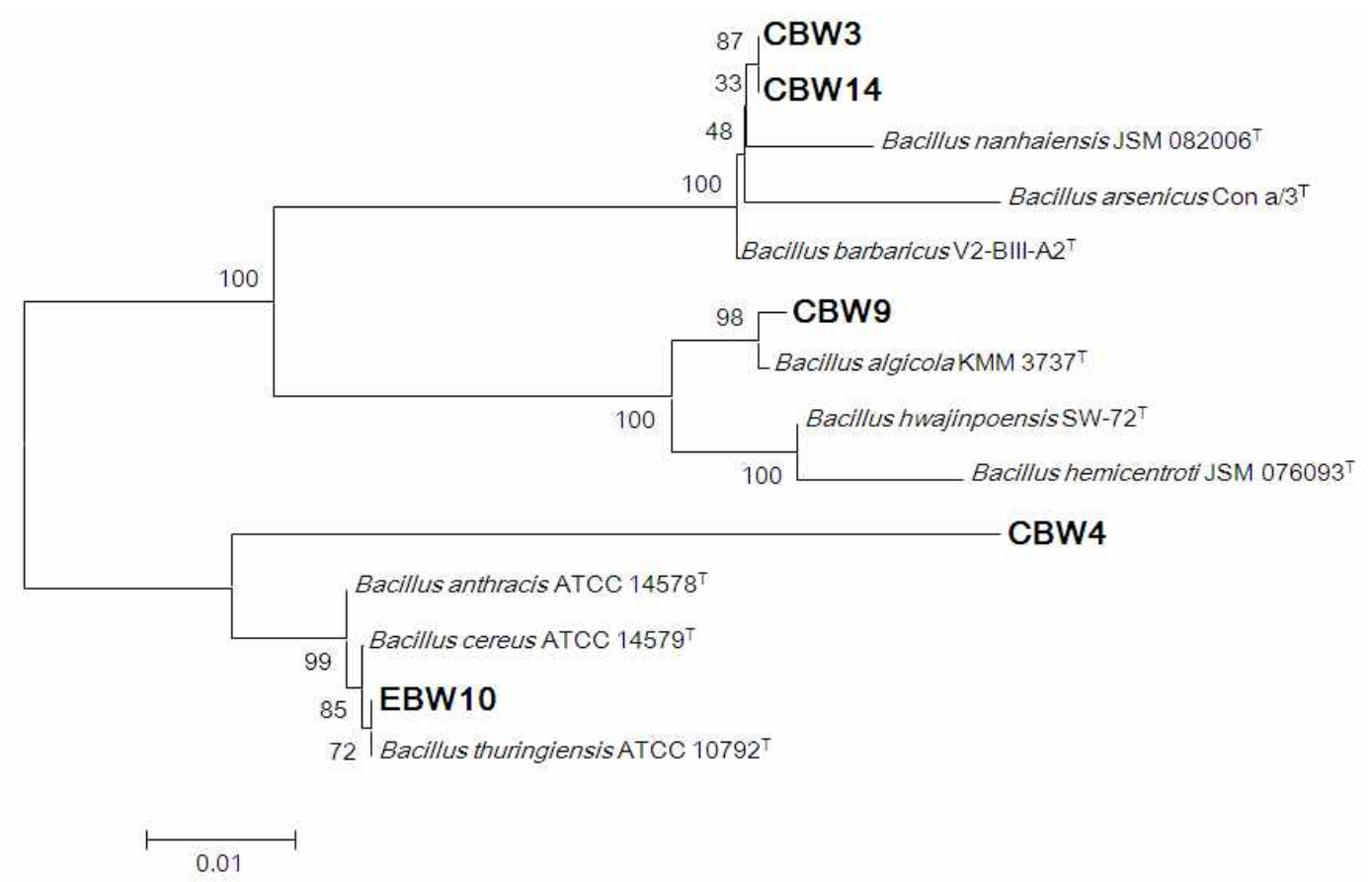

Fig. 1. Neighbour-joining tree based on $16 \mathrm{~S}$ rRNA gene sequences showing the phylogenetic relationships among Bacillus spp. isolated from polychaete (Perinereis aibuhitensis) and their closest neighbours of the genus Bacillus. Bootstrap values (expressed as percentages of 1000 replications) greater than $30 \%$ are given at the nodes. 
B. algicola KMM $3737^{\mathrm{T}}$ 는 갈조류인 Fucus evanescens에서 분리 한 세균으로 갈조류의 엽상체가 분해될 때 농화배양을 통해 분리된 것으로 알려져 있다[24]. CBW9은 B. anthracis ATCC $14578^{\mathrm{T}}$ 와도 높은 상동성을 가지는데 이 균주는 한국의 토양 에서 분리한 탄저병의 원인균으로 가축과 인간에게 치명적인 감염을 일으킨다[39]. EBW10은 B. thruingiensis ATCC $10792^{\mathrm{T}}$ 와 $16 \mathrm{~S}$ rRNA 유전자 염기서열에서 본 연구에서 비교대상으 로 정한 1376 개 염기서열 중 단 1 개가 달라 같은 종일 것으로 추정된다.

다양한 종류의 갯지렁이로부터 유래된 Bacillus 속 세균으로 는 alkaline protease를 생산하는 균주, Bacillus sp. [26] 등이 알려져 있으나 본 연구에서 사용한 갯지렁이(Perinereis aibuhitensis)의 미생물상에 대해서는 본 연구에서 처음으로 보고하 는 것으로 파악되었다. Bacillus는 수질 정화 능력을 통하여 배양 생물의 생존을 향상시키고 성장을 촉진하는데 긍정적 효과를 미칠 수 있다고 보고한 바 있다[17, 27, 33]. 최근 연구에 서 Bacillus sp. L14는 엄청난 양의 카드뮴을 축적할 수 있는 능력 때문에 생물학적 환경복원을 통한 중금속의 제거에 활용 될 수 있음을 보여주었으며[19], 또한 지질이 많이 포함되어 있는 유기물의 제거에도 lipase를 다량 생산하는 Bacillus 종들 이 활용될 수 있음을 보고한 바 있다[18]. 따라서 본 연구에서 얻어진 다양한 Bacillus 균주들에 대한 심층적인 연구의 가치 가 크다고 할 수 있다.

\section{배지별 Bacillus spp.의 생장능, 색소 생성 및 산화 발효능}

본 연구에서 사용한 5 종류의 Bacillus 균주들의 호기성 및 혐기성 조건에서의 생장능을 $30^{\circ} \mathrm{C}, \mathrm{MA}$ 배지에서 시험한 결과, 다섯 균주 모두 생장함을 확인하였다(Data not shown). MA.
LB agar, NA, TSA, R2A 등 5 개의 다른 배지를 이용하여 $30^{\circ} \mathrm{C}$, 호기성 조건에서 생장능을 시험한 결과, $\mathrm{CBW} 3, \mathrm{CBW} 4$, CBW14 그리고 EBW10은 모든 배지에서 생장하였지만 CBW9 은 LB에서는 약한 생장을 TSA에서 생장하지 않았다(Table 1). 이러한 사실은 본 연구에서 분리 사용한 Bacillus 균주들은 모 두 통성 호기성인 균주임을 제시해준다. 산화와 발효 중 어떤 방법으로 탄수화물을 이용하는지 알아보고자 기질로써 glucose를 첨가한 $\mathrm{OF}$ 배지에 균을 접종한 후 배양한 결과 CBW14 는 산화를 CBW3, CBW4, EBW10은 발효를 통해 당을 이용할 수 있었으며, 이들 균주들은 발효 산물로 산을 형성하지는 않 은 것으로 나타났다(Table 1). 또한 다섯 균주 중 CBW9 균주만 이 노란 오렌지색의 색소를 생성하는 것으로 나타났다.

\section{주요 환경 조건별 Bacillus spp.의 생장능}

실험 균주 모두가 $10-40^{\circ} \mathrm{C}$ 까지는 공통적으로 생장하였으며 $\mathrm{CBW} 14$ 는 $50^{\circ} \mathrm{C}$ 에서도 미약하게 성장하였다. CBW3와 CBW4 는 $4^{\circ} \mathrm{C}$ 에서도 잘 생장하였으며, $\mathrm{CBW} 14$ 와 $\mathrm{EBW} 10$ 은 약한 생 장을 나타내었다(Table 2). 따라서 CBW14는 $4-50^{\circ} \mathrm{C}$ 까지 넓은 범위에서 생장 할 수 있는 중온성 세균으로 분류되었다. 균주 $\mathrm{CBW} 9$ 와 계통관계가 가장 가까운 B. algicola [26]의 생장 온도 범위는 $10-45^{\circ} \mathrm{C}$ 로 $\mathrm{CBW} 9$ 의 생장 온도 범위와 일치하였다. $16 \mathrm{~S}$ rRNA 분석에서 B. barbaricus [48]과 계통관계가 가장 가까운 것으로 알려진 $\mathrm{CBW} 3$ 는 $45^{\circ} \mathrm{C}$ 에서는 생장하였으나 $50^{\circ} \mathrm{C}$ 에서 생장하지 않은 것으로 보아 생리학적 특성이 상당히 일치하는 것으로 나타났으나, 같은 종에 포함되는 CBW14은 미약하지 만 $50^{\circ} \mathrm{C}$ 에서도 생장하여 B. barbaricus의 생리학적 특성과 조금 다른 결과를 보였다.

배지의 염도를 달리하여 CBW3, CBW4, CBW9, CBW14 그

Table 1. Test for aerobic growth of Bacillus spp. isolated from polychaete (Perinereis aibuhitensis) in five different media, pigment production, and oxidation and fermentation (OF)

\begin{tabular}{lccccccc}
\hline Strain & MA & LB & NA & TSA & R2A & Pigment production & OF \\
\hline CBW3 & + & + & + & + & + & - & F \\
CBW4 & + & + & + & + & + & - & F \\
CBW9 & + & w & + & - & + & Yellowish orange & No action \\
CBW14 & + & + & + & + & + & - & O \\
EBW10 & + & + & + & + & + & - & F \\
\hline
\end{tabular}

+ : positive, -: negative, $\mathrm{w}$ : weak positive, $\mathrm{O}$ : oxidation, $\mathrm{F}$ : fermentation

Table 2. Effect of temperature on cell growth of Bacillus spp. isolated from polychaete (Perinereis aibuhitensis)

\begin{tabular}{|c|c|c|c|c|c|c|}
\hline \multirow{2}{*}{ Strain } & \multicolumn{6}{|c|}{ Temperature $\left({ }^{\circ} \mathrm{C}\right)$} \\
\hline & 4 & 10 & $15-35$ & 40 & 45 & 50 \\
\hline CBW3 & + & + & + & + & + & - \\
\hline CBW4 & + & + & + & + & + & - \\
\hline CBW9 & - & + & + & + & + & - \\
\hline CBW14 & $\mathrm{w}$ & + & + & + & + & $\mathrm{w}$ \\
\hline EBW10 & $\mathrm{w}$ & + & + & + & $\mathrm{w}$ & - \\
\hline
\end{tabular}

+: positive, -: negative, $\mathrm{w}$ : weak positive 
리고 EBW10 균주의 생장유무를 관찰한 결과 0-11\%까지는 5 종 모두 잘 생장하였다(Table 3). CBW3, CBW4 그리고 EBW10 은 11-17\% 염도 범위에서 균주에 따라 약간의 차이가 있었지 만 약한 생장을 하여 극고염 농도에서도 내성을 나타내는 중 호염성 세균(moderate halophile)일 것으로 사료되었다. $\mathrm{CBW} 3$ 및 CBW14와 계통관계에서 가장 가까운 것으로 분석된 B. barbaricus [46]은 $5 \% \mathrm{NaCl}$ 이상의 농도에서 생장하지 않아 비교 대상 균주들 간에는 생리학적 특성이 상당한 차이가 있 었다. 특히 CBW9는 본 연구에서 시험한 최고 농도인 $17 \%$ 에서 도 생장을 잘하였으며, 극호염성 세균(extremohalophile)의 생 장범위가 15-30\%라는 점을 고려해본다면 CBW9는 극호염성 환경에서도 살아가는 균으로 염분이 없는 환경에서부터 극고 염성 환경에 이르기까지 매우 폭 넓은 범위 염도 조건에서 생장할 수 있는 균으로 밝혀졌다. CBW9와 계통학적 관계가 가장 가까운 것으로 여겨지는 B. algioda [24]의 염분 내성 농도 인 $\mathrm{NaCl} 3 \%$ 이고 다른 균주인 B. arsenicus [42] 는 $2 \% \mathrm{NaCl}$ 에서 도 생장할 수 없는 것으로 나타나 CBW9와 이들 균주 간에는 염도 내성에 있어 상당한 차이가 있는 것으로 나타났다. 하지 만 $\mathrm{CBW} 9$ 와 $16 \mathrm{~S} \mathrm{rRNA}$ 상동성이 $97 \%$ 이상으로 계통관계가 가까운 균으로 나타난 B. hwajinponensis는 $15 \% \mathrm{NaCl}$ 에서는 생장하였으나 $20 \% \mathrm{NaCl}$ 에서는 생장하지 않은 것으로 알려져 있어[51] 본 연구에서 얻어진 결과와 어느 정도 일치하는 것으 로 나타났다. 이는 CBW9이 다른 균주들에 비하여 다양한 환 경에 잘 적응했음을 제시해준다.

본 연구에서 사용한 Bacillus 균주 CBW3, CBW4, CBW9, CBW14 그리고 EBW10 모두 pH 5-pH 9까지 생장하는 것으로 보아 약산성부터 약알칼리성에서 생장하였다(Table 4). B. barbaricus의 생장범위 $\mathrm{pH}$ 6.0-pH 9.5, B. algicola의 생장범위 $\mathrm{pH}$
7.0-pH 10, B. arsenicus의 생장범위 $\mathrm{pH}$ 5.5-pH 8.0, B. hwajimponensis의 생장범위 $\mathrm{pH}$ 5.0-pH 9.5를 고려해본다면, 본 연구에 서 분리 사용한 Bacillus 균주들은 생장 가능한 $\mathrm{pH}$ 범위에서 기존 알려진 Bacillus 균주들의 특성과 상당히 일치하였다.

\section{Bacillus spp.의 고분자물질 분해 효소 활성능}

Table 5는 DNA, cellulose, starch, casein 그리고 4 가지 Tween 등의 고분자 물질 을 사용하여 각 물질 분해에 관련된 효소 활성을 측정한 결과이다. DNA 물질이 포함된 배지에 $1 \mathrm{M} \mathrm{HCl}$ 을 떨어뜨렸을 때 DNase 활성을 갖고 있는 균주는 $\mathrm{DNA}$ 를 분해하여 균체 주변이 투명하게 변하는데 CBW3, $\mathrm{CBW} 4, \mathrm{CBW} 9, \mathrm{CBW} 14$ 그리고 EBW10 모두 균체 주변에 뚜렷 한 투명대를 형성하여 DNase 활성이 있었으며, 특히 CBW9와 CBW14는 크기가 매우 큰 투명대를 형성하여 DNase 활성이 매우 높음을 알 수 있었다. Cellulose 분해 여부를 관찰하고자 cellulose가 함유된 배지에 균을 48시간 배양한 뒤 congo-red $(0.1 \%)$ 로 염색, 30 분 후 $1 \mathrm{M} \mathrm{NaCl}$ 로 세척을 해 색을 관찰한 결과 오직 EBW10만이 균 주위에 희미한 노란색이 나타났다. 이는 CBW3, CBW4, CBW9, CBW14 균주는 cellulase 활성을 갖고 있지 않으며 EBW10균만이 Cellulose 분해에 필요한 cellulase 활성을 가지고 있음을 제시해준다. Starch 또는 casein 을 함유한 배지를 이용하여 그 분해능을 시험한 결과 본 연구 에서 사용한 모든 균주들이 다당류인 Starch 분해에 필요한 amylase와 단백질인 casein 분해에 필요한 효소 활성이 있음 을 알 수 있었다. Tween이 포함된 배지에서 균을 배양한 후 균체 주변이 뿌옇게 변하는 것을 확인한 결과 CBW14만 Tween 분해능이 없었으며 다른 균주들은 Tween 20, Tween 40, Tween 60, Tween 80 등 분자량이 다른 고분자 물질을 모두

Table 3. Effect of salinity on cell growth of Bacillus spp. isolated from polychaete (Perinereis aibuhitensis)

\begin{tabular}{|c|c|c|c|c|c|c|c|}
\hline \multirow{2}{*}{ Strain } & \multicolumn{7}{|c|}{ Salinity (\%) } \\
\hline & $0-11$ & 12 & 13 & 14 & 15 & 16 & 17 \\
\hline CBW3 & + & + & $w$ & $\mathrm{w}$ & $\mathrm{w}$ & $w$ & - \\
\hline CBW4 & + & + & $\mathrm{w}$ & $\mathrm{w}$ & $\mathrm{w}$ & - & - \\
\hline CBW9 & + & + & + & + & + & + & + \\
\hline CBW14 & + & + & + & + & $\mathrm{w}$ & $\mathrm{w}$ & - \\
\hline EBW10 & + & $\mathrm{w}$ & $\mathrm{w}$ & $\mathrm{w}$ & $\mathrm{w}$ & - & - \\
\hline
\end{tabular}

+: positive, -: negative, $\mathrm{w}$ : weak positive

Table 4. Effect of $\mathrm{pH}$ on cell growth of Bacillus spp. isolated from polychaete (Perinereis aibuhitensis)

\begin{tabular}{|c|c|c|c|c|c|c|c|c|c|}
\hline \multirow{2}{*}{ Strain } & \multicolumn{9}{|c|}{$\mathrm{pH}$} \\
\hline & 3 & 4 & 5 & 6 & 7 & 8 & 9 & 10 & 11 \\
\hline CBW3 & - & - & + & + & + & + & + & - & - \\
\hline CBW4 & - & - & + & + & + & + & + & + & - \\
\hline CBW9 & - & - & + & + & + & + & + & - & - \\
\hline CBW14 & - & - & + & + & + & + & + & - & - \\
\hline EBW10 & - & - & + & + & + & + & + & - & - \\
\hline
\end{tabular}

+: positive, -: negative 
분해할 수 있는 것으로 나타났다.

해양생물의 장내에서 발견되는 Bacillus균들은 다양한 유기 물을 분해할 수 있는 protease, amylase, cellulase 등의 효소들 을 생산할 수 있는 능력이 있는 것으로 보고된 바 있다[15, $49,52]$. 매우 흥미롭게도 CBW3 및 CBW14와 계통학적 관계가 가까운 것으로 여겨지는 B. barbaricus는 예상과는 달리 Tween 20과 Tween 80 등을 이용할 수 있는 능력이 없는 것으로 알려 져 있다[46]. 동해에서 분리된 것으로 균주 $\mathrm{CBW} 9$ 와 계통학적 관계가 가까운 것으로 여겨지는 B. hwajinponensis [51]은 caesin, starch, Tween 20, Tween 40, Tween 60, Tween 80 등을 분해할 수 있는 것으로 알려져 두 균주 간 특성이 매우 유사하
였다. 특히 균주 EBW10은 시험한 모든 고분자 물질을 분해하 여, protease, amylase, cellulase. lipase 등의 효소 활성을 가지 고 있을 것으로 추정되었다.

\section{Bacillus spp.의 탄소원 이용능 및 주요 효소 활성 분석}

균의 탄소원 이용 여부를 시험한 결과 5 균주 모두 amygalin, arbutin, cellobiose, esculin, fructose, glucose, glycerol, glycogen, maltose, ribose, salicin, starch, trehalose, a -methyl-D-mannoside, a-methyl-D-glucoside, N-acetyl-glucosamine 등을 잘 이용할 수 있는 것으로 나타났다(Table 6). 매우 흥미롭게도 탄소원으로 사용한 기질 중 erythritol,

Table 5. Evaluation of enzyme activities for the utilization of macromolecules in Bacillus spp. isolated from polychaete (Perinereis aibuhitensis)

\begin{tabular}{|c|c|c|c|c|c|c|c|c|}
\hline \multirow{2}{*}{ Strain } & \multirow{2}{*}{ DNA } & \multirow{2}{*}{ Cellulose } & \multirow{2}{*}{ Starch } & \multirow{2}{*}{ Casein } & \multicolumn{4}{|c|}{ Tween } \\
\hline & & & & & 20 & 40 & 60 & 80 \\
\hline CBW3 & $\mathrm{w}$ & - & + & + & + & + & + & + \\
\hline CBW4 & $\mathrm{w}$ & - & + & + & + & + & + & + \\
\hline CBW9 & + & - & $\mathrm{w}$ & + & $\mathrm{V}$ & + & + & + \\
\hline CBW14 & + & - & $\mathrm{w}$ & + & - & - & - & - \\
\hline EBW10 & $\mathrm{w}$ & + & + & + & + & + & + & + \\
\hline
\end{tabular}

+: positive, -: negative, $\mathrm{w}$ : weak positive, $\mathrm{v}$ : variable

Table 6. Test for utilization of carbohydrates by Bacillus spp. isolated from polychaete (Perinereis aibuhitensis)

\begin{tabular}{lccccc||cccccc}
\hline Substrate & CBW3 & CBW4 & CBW9 & CBW14 & EBW10 & Substrate & CBW3 & CBW4 & CBW9 & CBW14 & EBW10 \\
\hline Control & C & C & C & C & C & Esculin & + & + & + & + & + \\
Glycerol & + & + & + & + & + & Salicin & + & + & + & + & + \\
Erythritol & - & - & - & - & + & Cellobiose & + & + & + & + & + \\
D-Arabinose & - & - & - & - & + & Maltose & + & + & + & + & + \\
L-Arabinose & - & - & - & - & + & Lactose & + & + & - & + & - \\
Ribose & + & + & + & + & + & Melibiose & + & - & - & + & - \\
D-Xylose & - & - & - & - & + & Sucrose & + & - & + & + & + \\
L-Xylose & + & - & - & - & + & Trehalose & + & + & + & + & + \\
Adonitol & + & - & - & - & + & Inulin & - & - & - & + & + \\
B-Methyl-D-mannoside & + & - & - & - & - & Melezitose & - & - & - & + & + \\
Galactose & - & - & - & + & + & Raffinose & - & - & - & + & + \\
Glucose & + & + & + & + & + & Starch & + & + & + & + & + \\
Fructose & + & + & + & + & + & Glycogen & + & + & + & + & + \\
Mannose & - & - & + & + & + & Xylitol & - & - & - & + & + \\
Sorbose & - & - & - & - & + & Gentiobiose & + & - & - & + & + \\
Rhamnose & - & - & - & - & + & D-Turanose & - & - & + & + & - \\
Dulcitol & - & - & - & - & + & D-Lyxose & - & - & - & + \\
Inositol & - & - & - & - & + & D-Tagatose & - & - & - & + \\
Mannitol & - & - & - & - & + & D-Fucose & - & - & - & + \\
Sorbitol & - & - & - & - & + & L-Fucose & - & - & - & + \\
a-Methyl-D-mannoside & + & + & + & + & + & D-Arabitol & - & - & - & + \\
a-Methyl-D-glucoside & + & + & + & + & + & L-Arabitol & - & - & - & + \\
N-Acetyl-glucosamine & + & + & + & + & + & Gluconate & - & - & - & + \\
Amygdalin & + & + & + & + & + & 2-keto-Gluconate & - & - & + & + \\
Arbutin & + & + & + & + & + & 5-keto-Gluconate & - & - & + & + & + \\
\hline
\end{tabular}


D-arabinose, L-arabinose, D-xylose, sorbose, rhamnose, dulcitol, inositol, mannitol, sorbitol 등은 오직 균주 EBW10만이, D-lyxose, D-tagatose, D-fucose, L-fucose, D-arabitol, L-arabitol, gluconate 등은 균주 CBW14만이 이용할 수 있었고, $\beta$ -methyl-D-xyloside는 CBW3만이 이용할 수 있었다. 매우 특 이한 점은 B. barbaricus [48]과 계통관계가 가장 가까운 것으로 알려진 CBW3과 CBW14간에 탄소 이용능에 있어 상당한 차이 가 있었다. CBW14는 CBW3 균주에 비해 훨씬 많은 종류의 기질들을 탄소원으로 이용할 수 있는 것으로 나타났다. CBW9 와 상동성을 가지는 B. algicola [24]는 ribose, D-arabinose, D-mannose, gluconate를 이용하지 못하는 것으로 나타났으 나, CBW 9는 D-arabinose, D-mannose, gluconate는 이용하지
못하였으나 ribose를 이용할 수 있는 것으로 나타나 2 균주 간에는 생리학적 특성이 조금 다른 것으로 나타났다. B. thuringiensis [5]와 가장 상동성이 높은 것으로 나타난 균주 EBW10 도 매우 많은 수의 기질들을 탄소원으로 이용할 수 있었다.

$\mathrm{API} \mathrm{ZYM} \mathrm{kit을} \mathrm{이용해} \mathrm{갯지렁이에서} \mathrm{분리} \mathrm{선별한} 5$ 균주의 효소활성을 시험한 결과 대상 균주 5 종 모두 alkaline phosphatase 활성을 가지며, CBW3, CBW4 그리고 EBW10은 acid phospatase 활성을 동시에 가지는 것으로 나타났다(Table 7). CBW3, CBW9 그리고 EBW10은 arginine dihydrolase 양성 반응을, CBW4와 CBW14는 arginine dihydrolase 음성반응을 나타냈다. 시험한 균주 중 CBW4만 a-chymotrypsin 양성반응 을 보였고, CBW3, CBW14, EBW10은 esterase (C4) 활성을,

Table 7. Enzyme assay for major biochemical reactions in Bacillus spp. from polychaete (Perinereis aibuhitensis)

\begin{tabular}{lccccc}
\hline Enzyme assayed for & CBW3 & CBW4 & CBW9 & CBW14 & EBW10 \\
\hline Acid phosphatase & + & + & - & - & + \\
Alkaline phosphatase & + & + & + & + & + \\
Arginine dihydrolase & + & - & + & - & + \\
a-Chymotrypsin & - & + & - & - & - \\
Esterase (C4) & + & - & + & + & + \\
Esterase lipase (C8) & + & - & + & - & + \\
Gelatinase & - & + & - & - \\
B-Glucosidase & - & + & - & - \\
Leucine arylamidase & + & + & - & + \\
Lysine decarboxylase & - & - & + & - & + \\
Naphtol-AS-BI-phosphohydrolase & + & - & - & - & + \\
\hline
\end{tabular}

t: positive, -: negative

Table 8. Fatty acid composition (\%) of Bacillus spp. isolated from polychaete (Perinereis aibuhitensis).

\begin{tabular}{|c|c|c|c|c|c|}
\hline Fatty acid & CBW3 & CBW4 & CBW9 & CBW14 & EBW10 \\
\hline iso $\mathrm{C}_{14: 0}$ & 9.4 & 6.6 & 8.6 & 9.4 & 6.4 \\
\hline $\mathrm{C}_{14: 0}$ & 0.7 & 0.7 & 0.6 & 0.6 & 0.9 \\
\hline iso $\mathrm{C}_{15: 1} \mathrm{AT}$ & 0.7 & - & - & 0.5 & - \\
\hline iso $\mathrm{C}_{15: 0}$ & 19.0 & 46.9 & 5.5 & 17.0 & 22.8 \\
\hline anteiso $\mathrm{C}_{15: 0}$ & 42.8 & 22.2 & 55.7 & 47.1 & 45.7 \\
\hline $\mathrm{C}_{15: 0} 2-\mathrm{OH}$ & - & - & - & - & - \\
\hline $\mathrm{C}_{15: 0}$ & 0.9 & 0.5 & 2.4 & 1.2 & 0.5 \\
\hline $\mathrm{C}_{16: 1} \omega 7 \mathrm{c}$ & 3.7 & - & - & 2.8 & 1.2 \\
\hline iso $\mathrm{C}_{16: 0}$ & 7.1 & 6.2 & 9.0 & 6.0 & - \\
\hline $\mathrm{C}_{16: 1 \omega 9 \mathrm{c}}$ & 2.4 & 1.8 & 1.2 & 2.8 & 1.6 \\
\hline $\mathrm{C}_{16: 1 \omega 11 \mathrm{c}}$ & 2.8 & 1.3 & 1.8 & 2.4 & 1.2 \\
\hline $\mathrm{C}_{16: 0}$ & 2.0 & 0.5 & 0.9 & 1.2 & 1.0 \\
\hline $\mathrm{C}_{16: 1 \omega 7 \mathrm{c} \text { alcohol }}$ & 2.6 & 8.0 & 6.4 & 3.2 & 7.6 \\
\hline iso $\mathrm{C}_{17: 0}$ & - & 0.8 & - & 0.6 & - \\
\hline iso $\mathrm{C}_{17: 1 \omega 10 \mathrm{c}}$ & - & 1.2 & - & - & 2.0 \\
\hline anteiso $\mathrm{C}_{17: 0}$ & - & 3.2 & 7.3 & 2.0 & 1.8 \\
\hline anteiso $\mathrm{C}_{17: 1} \mathrm{~A}$ & 2.6 & - & 0.5 & 0.8 & 1.2 \\
\hline Summed Feature $2^{*}$ & 1.1 & - & - & 1.5 & 3.8 \\
\hline
\end{tabular}

"Summed features represent groups of two or three fatty acids that could not be separated by GLC with the MIDI system. Summed feature 2 contained one or more of following fatty acids: iso- $\mathrm{C}_{16: 1} \mathrm{I}$ and/or 2-OH and/or $\mathrm{C}_{14: 0} 3-\mathrm{OH}$. Fatty acids amounting to less than $0.5 \%$ in all strains tested are not listed. tr, Trace $(<0.5 \%)$; -, not detected. All data from this study. 
CBW3, CBW9, EBW10은 esterase lipase (C8) 활성을 나타냈 다. $\mathrm{CBW}$ 를 제외한 4 균주는 gelatinase 활성을 가지며, $\beta$ -Glucosidase 활성은 $\mathrm{CBW} 4$ 에서만 관찰되었다. $\mathrm{CBW}$, CBW4, EBW10은 leucine arylamidase 활성을 가지는 반면, $\mathrm{CBW}$ 와 $\mathrm{CBW} 14$ 는 leucine arylamidase 활성을 갖고 있지 않 았다. Lysine decarboxylase는 CBW9와 EBW10에서, Naphtol-AS-BI-phosphohydrolase 활성은 CBW3과 EBW10에 서 관찰되었다. 특히 시험한 모든 고분자 물질을 분해할 수 있는 것으로 밝혀진 균주 EBW10은 esterase (C4)와 esterase (C8)의 활성을 갖고 있는 것으로 밝혀져 산업적 활용 범위가 매우 클 것으로 사료되며, 다른 Bacillus 세균들은 용도에 따라 산업적 활용 가치가 있다고 할 수 있다.

\section{Bacillus spp.의 지방산 분석}

본 연구에서 사용한 CBW3, CBW4, CBW9, CBW14 그리고 EBW10 등 5 균주 모두에서 주요 지방산으로 anteiso $\mathrm{C}_{150 . \text {, iso }}$, $\mathrm{C}_{15: 0,}$, iso $\mathrm{C}_{14: 0,}$, iso $\mathrm{C}_{16: 0}$ 그리고 $\mathrm{C}_{16: 1} \omega 7 \mathrm{c}$ alcohol 등이 나타났다 (Table 8). CBW3, CBW9, CBW14, EBW10 균주에서는 anteiso $\mathrm{C}_{15: 0}$ 이 균주에 따라 차이가 있었지만 약 $42.8 \%$ 에서 $55.7 \%$ 까지 가장 많은 비율을 차지하는 지방산으로 분석되었고, 오직 $\mathrm{CBW} 4$ 에서만 iso $\mathrm{C}_{15: 0}$ 이 분석된 전체 지방산의 $46.9 \%$ 를 차지 하였고 anteiso $\mathrm{C}_{15.0}$ 은 $22.2 \%$ 비율로 나타났다. iso $\mathrm{C}_{15: 0}$ 의 경우 $\mathrm{CBW} 3, \mathrm{CBW} 9, \mathrm{CBW} 14, \mathrm{EBW} 10$ 균주에서 그 비율이 최저 5.5\% 에서 $22.8 \%$ 까지 매우 다양하게 나타났다. 많은 Bacillus 균주의 세포막 지방산 분석에서 가장 큰 비율로 나타나는 주요 지방 산으로는 iso $\mathrm{C}_{15: 0}$ 과 anteiso $\mathrm{C}_{1500}$ 으로 알려져 있으나 균주마다 이들의 비율은 상당한 차이를 나타내고 있다[42, 46, 51].

결론적으로 본 연구에서 분리한 다섯 균주 중, CBW4 균주 는 기존 알려진 균주와 계통학적 관계가 상당히 먼 것으로 나타나 신종일 가능성이 매우 높은 것으로 사료되었다. 본 연 구에서 분리한 균주들과 가장 가까운 균주들과의 유전학적 특성과 생리생화학적 특성 비교 분석에서, 시험 항목에 따라 비교 대상 균주들 간에는 차이가 많이 존재하는 것으로 나타 났다.

\section{감사의 글}

본 연구는 2010-2012년도 농림수산식품기술기획평가원의 연구개발사업비의 연구지원으로 수행되었으며, 이에 감사드 립니다.

\section{References}

1. Arena, A., Maugeri, T. L., Pavone, B., Iannello, D., Gugliandolo, C. and Bisignano, V. 2006. Antiviral and immunoregulatory effect of a novel exopolysaccharide from a marine thermotolerant Bacillus licheniformis. Int
Immunopharmacol 6, 8-13.

2. Bagheri, T., Hedayati, S. A., Yavari, V., Alizade, M. and Farzanfar, A. 2008. Growth, survival and gut microbial load of rainbow trout (Onchorhynchus mykiss) fry given diet supplemented with probiotic during the two months of first feeding. Turk J Fish Aquat Sci 8, 43-48.

3. Banerjee, S., Devaraja, T. N., Shariff, M. and Yusoff, F. M. 2007. Comparison of four antibiotics with indigenous marine Bacillus spp. in controlling pathogenic bacteria from shrimp and artemia. J Fish Dis 30, 383-389.

4. Bishop, P. J. and Neuman, G. 1970. The history of the Ziehl-Neelsen stain. Tubercle 51, 196.

5. Boulygina, E. S., Ignatov, A. N., Tsygankova, S. V., Korotkov, E. V. and Kuznetsov, B. B. 2009. Interspecies relations between Bacillus thuringiensis strains studied by $\mathrm{AP}-\mathrm{PCR}$ and sequence analysis of ribosomal operon regions. Microbiol 78, 703-710.

6. Bryan, G. W. and Gibbs, P. E. 1987. Polychaete common ragworms as indicators of heavy-metal availability in marine deposits. In : Biological Processes and Wastes in the Oceans (Capuzzo J. M., Kester D. R., eds.). Malabar, Florida : Robert E Krieger Publishing Co, 37-39.

7. Campos, L. C., Su, M. F. J., Graham, N. J. D. and Smith, S. R. 2002. Biomass development in slow sand filters. Water Res 36, 4543-4551.

8. Chun, J., Lee, J. H., Jung, Y., Kim, M., Kim, S., Kim, B. K. and Lim, Y. W. 2007. EzTaxon : a web-based tool for the identification of prokaryotes based on 16S ribosomal RNA gene sequences. Int J Syst Evol Microbiol 57, 2259-2261.

9. Davidson, J., Helwig, N. and Summerfelt, S. T. 2008. Fluidized sand biofilters used to remove ammonia, biochemical oxygen demand, total coliform bacteria, and suspended solids from an intensive aquaculture effluent. Aquacult Engineer 39, 6-15.

10. Edwards, P. R. and Bruner, D. W. 1942. Serological identification of Salmonella cultures. Circ Ky Agric Exp Sta 54, 35.

11. Felsenstein, J. 1985. Confidence limits on phylogenies : an approach using the bootstrap. Evol 39, 783-791.

12. Fourcy, D., Jumel, A., Heydorff, M. and Lagadic, L. 2002. Esterases as biomarkers in Nereis (Hediste) diversicolor exposed to temephos and Bacillus thuringiensis var. israelensis used for mosquito control in coastal wetlands of Morbihan (Brittany, France). Mar Environ Res 54, 755-759.

13. Fujioka, Y., Shimoda, T. and Srithong, C. 2007. Diversity and community structure of macrobenthic fauna in shrimp aquaculture ponds of the Gulf of Thailand. Jap Agric Res Quart 41, 163-172.

14. Gatesoupe, F. J. 1999. The use of probiotics in aquaculture. Aquacult 180, 147-165.

15. Ghosh, K., Sen, S. K. and Ray, A. K. 2002. Characterization of bacilli isolated from the gut of rohu, Labeo rohita fingerlings and its significance in digestion. I Appl Aquacult 12, 33-42.

16. Gili, J. M. and Coma, R. 1998. Benthic suspension feeders : their paramount role in littoral marine food webs. Trends Ecol Evol 13, 316-321. 
17. Gomez-Gil, B., Roque, A. and Turnbull, J. F. 2000. The use and selection of probiotic bacteria for use in the culture of larval aquatic organisms. Aquacult 191, 259-270.

18. Guncheva, M. and Zhiryakova, D. 2011. Catalytic properties and potential applications of Bacillus lipases. $J$ Mol Cat B $\therefore$ Enzym 68, 1-21.

19. Guo, H., Luo, S., Chen, L., Xiao, X., Xi, Q., Wei, W., Zeng, G., Liu, C., Wan, Y. and Chen, J. 2010. Bioremediation of heavy metals by growing hyperaccumulaor endophytic bacterium Bacillus sp. L14. Bioresour Technol 101, 8599-8605.

20. Hall, T. 2007. BioEdit. Biological sequence alignment editor for Win95/98/ NT/2K/XP. Carlsbad, CA : Ibis Biosciences.

21. Hovda, M. B., Sivertsvik, M., Lunestad, B. T., Lorentzen, G. and Rosnes, J. T. 2007. Characterisation of the dominant bacterial population in modified atmosphere packaged farmed halibut (Hippoglossus hippoglossus) based on $16 \mathrm{~S}$ rDNA-DGGE. Food Microbiol 24, 362-371.

22. Hucker, G. J. and Cohn, H. J. 1923. Methods of gram staining. N.Y. State Agr Exp Sta Tech Bull 93, 123.

23. Hugh, R. and Leifson, E. 1953. The taxonomic significance of fermentative versus oxidative metabolism of carbohydrates by various Gram negative bacteria. J Bacteriol 66, 24-26.

24. Ivanova, E. P., Alexeeva1, Y. A., Zhukova, N. V., Gorshkova, N. M., Buljan, V., Nicolau, D. V., Mikhailov, V. V. and Christen, R. 2004. Bacillus algicola sp. nov, a novel filamentous organism isolated from brown alga Fucus evanescens. Syst Appl Microbiol 27, 301-307.

25. Jeffries, C. D., Holtman, D. F. and Guse, D. G. 1957. Rapid method for determining the activity of microorganisms on nucleic acids. J Bacteriol 75, 590-591.

26. Joo, H.-S., Kumar, C. G., Park, G.-C., Paik, S. R. and Chang, C.-S. 2004. Bleach-resistant alkaline protease produced by a Bacillus sp. isolated from the Korean polychaete, Periserrula leucophryna. Pro Biochem 39, 1441-1447.

27. Kennedy, S. B., Tucker, J. W., Neidig, C. L., Vermeer, G. K., Cooper, V. R., Jarrell, J. L. and Sennett, D. G. 1998. Bacterial management strategies for stock enhancement of warm water marine fish : a case study with common snook (Centropomus undecimalis). Bull Mar Sci 62, 573-588.

28. Kovács, N. 1928. Eine vereinfachte methode zum Nachweis der indolbildung durch bakterien. $Z$ Immum Forsch Exp Ther $55,311$.

29. Kumar, S., Nei, M., Dudley, J. and Tamura, K. 2008. MEGA : a biologist-centric software for evolutionary analysis of DNA and protein sequences. Brief Bioinform 9, 299-306.

30. Lane, D. J. 1991. 16S/23S rRNA sequencing. In Nucleic Acid Techniques in Bacterial Systematics, pp. 115-175. In Stackebrandt, E. and Goodfellow, M. (eds.), New York : Wiley.

31. Mikesell, M. D., Kukor, J. J. and Olsen, R. H. 1993. Metabolic diversity of aromatic hydrocarbon-degrading bacteria from a petroleum-contaminated aquifer. Biodegradation 4, 249-259.

32. Moeller, M. 1891. Ueber eine neue Methode der Sporenfarbung. Zbl Bakt, I Abt Orig 10, 273-277.

33. Moriarty, D. J. W. 1998. Control of luminous Vibrio species in penaeid aquaculture ponds. Aquacult 164, 351-358.

34. Orejas, C., Gili, J. M., Arntz, W. E., Ros, J. D., Lo"Lpez, P. J., Teixido"L, N., Filipe, P. 2000. Benthic suspension feeders, key players in Antarctic marine ecosystems. Contribut SCi 1, 299-311.

35. Palacios, G. L. and Timmons, M. B. 2001. Determining design parameters for recovery of aquaculture wastewater using sand beds. Aquacult Engineer 24, 289-299.

36. Pérez, E., Blasco, J. and Solé, M. 2004. Biomarker responses to pollution in two invertebrate species : Scrobicularia plana and Nereis diversicolor from the Cádiz bay (SW Spain). Mar Environ Res 58, 275-279.

37. Prieur, D., Mével, G., Nicolas, J. L., Plusquellec, A. and Vigneulle, M. 1990. Interactions between bivalve molluscs and bacteria in the marine environment. Oceanography Mar Biol : Annual Rev 28, 277-352.

38. Raida, M. K., Larsen, J. L., Nielsen, M. E. and Buchmann, K. 2003. Enhanced resistance of rainbow trout, Oncorhynchus mykiss (Walbaum), against Yersinia ruckeri challenge following oral administration of Bacillus subtilis and B. licheniformis (BioPlus2B). J Fish Dis 26, 495-498.

39. Ryu, C., Lee, K., Hawng, H.-J., Yoo, C.-K., Seong, W.-K. and Oh, H.-B. 2005. Molecular characterization of Korean Bacillus anthracis isolates by amplified fragment length polymorphism analysis and multilocus variable-number tandem repeat analysis. Appl Environ Microbiol 71, 4664-4671.

40. Saitou, N. and Nei, M. 1987. The neighbor-joining method : a new method for reconstructing phylogenetic trees. $\mathrm{Mol}$ Biol Evol 4, 406-425.

41. Sambrook, J. and Russel, D. W. 2001. Molecular cloning. Cold Spring Harbor Laboratory Press, Cold Spring Harbor, N.Y.

42. Shivaji, S., Suresh, K., Chaturvedi, P., Dube, S. and Sengupta, S. 2005. Bacillus arsenicus sp. nov., an arsenic-resistant bacterium isolated from a siderite concretion in West Bengal, India. Int J Syst Evol Microbiol 55, 1123-1127.

43. Sierra, G. 1957. A simple method for the detection of lipolytic activity of microorganisms and some observations on the influence of the contact between cells and fatty substrates. Ant van Leeuwen 23, 15.

44. Stabili, L., Licciano, M., Giangrande, A., Fanelli, G. and Cavallo, R. S. 2006. Sabella spallanzanii filter-feeding on bacterial community: ecological implications and applications. Mar Environ Res 61, 74-92.

45. Sugita, H., Hirose, Y., Matsuo, N. and Deguchi, Y. 1998. Production of the antibacterial substance by Bacillus species strain NM12, an intestinal bacterium of Japanese coastal fish. Aquacult 165, 269-280.

46. Täubel. M., Kämpfer, P., Buczolits, S., Lubitz, L. and Busse, H.-J. 2003. Bacillus barbaricus sp. nov., isolated from an experimental wall painting. Int J Syst Evol Microbiol 53, 725-730.

47. Thompson, J. D., Gibson, T. J., Plewniak, F., Jeanmougin, F. and Higgins, D. G. 1997. The clustal_x windows interface : flexible strategies for multiple sequence alignment aided by quality analysis tools. Nucleic Acids Res 25, 4876-4882. 
48. Vaseeharan, B. and Ramasamy, P. 2003. Control of pathogenic Vibrio spp. by Bacillus subtilis BT23, a possible probiotic treatment for black tiger shrimp Penaeus monodon. Lett Appl Microbiol 36, 83-87.

49. Verschuere, L., Rombaut, G., Sorgeloos, P. and Verstraete, W. 2000. Probiotic bacteria as biological control agents in aquaculture. Microbiol Mol Biol Res 64, 655-671.

50. Vigneswaran, S., Ngo, H. H. and Wee, K. L. 1999. Effluent recycle and waste minimisation in prawn farm effluent. $J$ Cleaner Prod 7, 121-126.

51. Yoon, J. H., Kim, I.-G., Kang, K. H., Oh, T.-K. and Park,
Y.-H. 2004. Bacillus hwajinponensis sp. nov. and an unnamed Bacillus genomospecies, novel members of Bacillus rRNA group 6 isolated from sea water of the East Sea and the Yellow Sea in Korea. Int J Syst Evol Microbiol 54, 803-808. 52. Ziaei-Nejad, S., Rezaeib, M. H., Takamic, G. A., Lovettd, D. L., Mirvaghefia, A. and Shakourie, M. 2006. The effect of Bacillus spp. bacteria used as probiotics on digestive enzyme activity, survival and growth in the Indian white shrimp Fenneropenaeus indicus. Aquacult 252, 516-524.

\section{초록 : 갯지렁이(Perinereis aibuhitensis)에서 분리한 Bacillus spp.의 생리생화학적 특성 분석}

신세연 ${ }^{1}$ - Khorloo Yundendorj ${ }^{1}$ 이상석 ${ }^{2}$ - 강경호 ${ }^{3}$ - 강형일 ${ }^{1}$ *

(순천대학교 환경교육과, ${ }^{2}$ 순천대학교 동물자원학과, ${ }^{3}$ 전남대학교 수산양식학부)

본 연구에서는 연안 갯벌에서 유기물 분해능이 매우 우수한 것으로 알려진 갯지렁이(Perinereis aibuhitensis)에 내생하고 있는 균주 중 호기성과 혐기성 조건에서 생장 가능한 5 종류의 Bacillus 균주 CBW3, CBW4, CBW9, CBW14 그리고 EBW10를 선별하여 그 특성을 비교 분석하였다. $16 \mathrm{~S} \mathrm{rRNA}$ 염기서열에 기초하여 동정한 결과, CBW3과 CBW14는 B. nanhaiensis, B. arsenicus 그리고 B. barbaricus와 99.8\% 이상의 높은 상동성을, CBW4, CBW9 그리고 EBW10 균주는 B. anthracis, B. algicoa 그리고 B. thuringiensis와 각각 $92.7 \%, 99.8 \%$ 그리고 $99.8 \%$ 의 상동성 을 보였다. 이들 대부분 균주들의 생장온도 범위는 $4-45^{\circ} \mathrm{C}$, 염도는 0-17\%, $\mathrm{pH}$ 는 5-9 범위로 매우 다양하게 나타났 다. 모든 균주들이 casein, starch 분해 효소를 가지고 있었으며 특히 균주 EBW10은 시험한 모든 고분자 물질을 분해할 수 있는 protease, amylase, cellulase. lipase 등의 효소 활성을 가지고 있을 가능성이 높음을 제시해주었 다. 대상 균주 5 종 모두 alkaline phosphatase 활성을 가지며, CBW3, CBW4 그리고 EBW10은 acid phospatase 활성을 동시에 가지고 있었으며, CBW3, CBW14, EBW10은 esterase (C4) 활성을, CBW3, CBW9, EBW10은 CBW4 는 esterase lipase (C8) 활성을 나타냈다. 지방산 분석 결과 CBW3, CBW9, CBW14, EBW10 균주에서는 anteiso $\mathrm{C}_{15: 0}$ 이 균주에 따라 차이가 있었지만 약 $42.8 \%$ 에서 $55.7 \%$ 까지 가장 많은 비율을 차지하는 지방산으로 분석되었 고, 오직 $\mathrm{CBW} 4$ 에서만 iso $\mathrm{C}_{15: 0}$ 이 전체 지방산의 $46.9 \%$ 로 가장 많은 비율로 나타났다. 